\title{
Beyond Application. The Case of Environmental Ethics
}

\section{Más allá de la aplicación. El caso de la ética ambiental}

\author{
Luca Valera \\ Pontificia Universidad Católica de Chile \\ Chile \\ luvalera@uc.cl \\ https://orcid.org/0000-0002-1693-396X \\ Gabriel Vidal \\ Pontificia Universidad Católica de Chile \\ Chile \\ gtvidal@uc.cl \\ Yuliana Leal \\ Pontificia Universidad Católica de Chile \\ Chile \\ yleal1@uc.cl.
}

Recibido: 17 - 11 - 2018.

Aceptado: 19 - 03 - 2019.

Publicado en línea: 28 - 10 - 2020. 


\begin{abstract}
Environmental ethics is often seen as a branch of applied ethics whose task is to offer solutions to emerging ethical dilemmas in the context of ecology. In this paper, we challenge this assumption, showing how the object of environmental ethics raises questions that go beyond that of applied ethics. We explore how the environmental issues bring up the need to inquire into the ontological status of Nature and the place of human beings in it, raising more general and far-reaching questions that do not get entrapped in the mere application. In this regard, it appears that "dwelling", in its ontological sense, is at the bottom of these questions, creating a bridge between the ontological and the practical realm. Finally, we review classical environmental ethics' paradigms highlighting the elements that go beyond applied ethics. And so, taking into account the different environmental ethics paradigms, we have two options: reducing the scope of the discipline and exclude the models that exceed it, or reconsidering it as an environmental philosophy tout court.

Keywords: environmental ethics; environmental philosophy; applied ethics; dwelling; nature; environmental ethics paradigms; Martin Heidegger.
\end{abstract}

\title{
Resumen
}

La ética ambiental es usualmente vista como una rama de la ética aplicada cuya tarea es ofrecer soluciones a los dilemas éticos emergentes en el contexto de la ecología. En este artículo cuestionamos esta suposición mostrando cómo el objeto de la ética ambiental suscita preguntas y cuestiones que van más allá de las consideraciones de la ética aplicada. Exploramos cómo las cuestiones ambientales reanudan la necesidad de preguntarse por el estatuto ontológico de la Naturaleza y el lugar de los seres humanos en ella, suscitando así preguntas más generales y de amplio alcance que no quedan atrapadas en la mera aplicación. Respecto a esto, el sentido ontológico del "habitar" aparece en el fondo de estas preguntas, estableciendo un puente entre lo ontológico y lo práctico. Finalmente, revisamos los paradigmas clásicos de la ética ambiental, destacando aquellos elementos que van más allá de las éticas aplicadas. Así, considerando los diferentes paradigmas éticos ambientales, tenemos dos opciones: reducir el alcance de la disciplina y excluir los modelos que la exceden, o bien, reconsiderar la disciplina como una filosofía ambiental tout court.

Palabras clave: ética ambiental; filosofía ambiental; ética aplicada; habitar; naturaleza; paradigmas de ética ambiental; Martin Heidegger. 


\section{Is Environmental Ethics Really (Only) Applied Ethics? ${ }^{1}$}

The aim of this paper is to raise questions about the epistemological status of environmental ethics after half a century of history, the emergence of its problems and new challenges, as well as the construction of a new ecological awareness and the consolidation of the "ethicalenvironmental" issue at the academic level and that of the general public (cfr. Singer, 1986, p. 6). Environmental ethics is usually defined as applied ethics focused on our responsibility for the environment (cfr. Bordeau, 2004, p. 13). ${ }^{2}$ However, defining applied ethics is a complex task. We can begin to shed light on this if we understand it as one of the disciplines tasked with studying human actions in order to determine what is right in a given context.

It is probably a consensus that it is possible to divide ethics into three main areas: meta-ethics, normative ethics and applied ethics (cfr. Bordeau, 2004, p. 13). The first is concerned with purely theoretical reflection about the nature of morality itself or the possibility of its existence. The second one deals with the formulation of moral principles or the formulation of an ultimate moral principle. The last is concerned with how these principles are applied to concrete situations (cfr. Morscher, Neumaier, \& Simons, 2012, p. IX). ${ }^{3}$ Concerning the latter, despite the different conceptions of "application," ${ }^{4}$ there is a certain definition that

1 Funding was provided by VRI/DPCC, Pontificia Universidad Católica de Chile (Grant No. 7690/DPCC2016).

2 Others define it as "the branch of applied philosophy devoted to exploring values in and duties to nonhuman nature" (Minteer \& Collins, 2008, p. 484). It is worth noticing that environmental ethics had its origin as "land ethics," with the famous book by Aldo Leopold (1949), A Sand Country Almanac and Sketches Here and There.

3 Although some recognize that "there is a potentially important distinction to be made between 'applied' and 'practical' ethics" (Minteer \& Collins, 2008, p. 484). It is almost always preferable to use the adjective "applied" to define ethics, to place it in a semantic area well-recognized academically as that of Applied Ethics.

4 It has been questioned whether application consists of an engineering approach, for example, in which universal mathematical principles are applied. The relationship between theory and practice is also questionable. Cortina (2007, 
seems acceptable for all applied ethics, namely, that they "seek to apply the ethical principles [...] to the different areas of daily life" (Cortina, 1996, p. 121).

One of the most critical issues that can help us elucidate the essence of applied ethics is the idea of "application," which is often interpreted too hastily. In Truth and Method, Hans Georg Gadamer (2013, p. 350) offered a valuable interpretation of this concept, stating: "Application does not mean first understanding a given universal in itself and then afterward applying it to a concrete case. It is the very understanding of the universal [...] itself." In this sense, application not only means "mechanical reproduction on to the particular," but also implies knowledge of the universal and creativity to give an interpretation to the specific situation.

From this perspective, there are many "subdisciplines" under the term "applied ethics" as possible contexts of application. In contrast, if we understand "application" as a framework "in which justified conclusions are deduced from a preexisting theoretical structure of normative precepts that cover the judgment" (Beauchamp, 2007, p. 57), ${ }^{5}$ applied ethics is reduced to a mere logical-mathematical calculation. ${ }^{6}$

Following the "hermeneutic" model of application, we can affirm that each area of social life, as it presents problematic situations and ethical dilemmas, reveals the need to draw upon moral reflection that specializes in its problems and peculiarities, without losing awareness of what is "universal." In this way, many specialties of applied ethics emerge, like business ethics, bioethics, communication ethics, engineering ethics, and others. Each kind of applied ethics consists in specialized reflections on a specific area of social life. For example, medical ethics is concerned with ethical dilemmas that can emerge in medical practice, such as euthanasia, abortion, high-risk procedures, organ transplantation, among others. Applied ethics provides the

pp. 167-169) questions why the application is merely inductive, deductive or casuistic, and proposes critical hermeneutics. Given this problem, LaFollette (2005, p. 8) preferred the term "ethical practice."

5 The same Beauchamp (2007, p. 57), one of the fathers of principlism in bioethics, defines this research methodology as "deductivism."

6 In Beauchamp's words (2007, p. 57): “In short, the method of reasoning at work is the application of a valid general norm to a clear case falling under the norm, thereby reaching the correct conclusion." 
theoretical tools in these situations for professionals to interpret and take concrete decisions with regards to morally problematic situations.

A notable feature of applied ethics is that they do not generally question the factuality of the context of their application (cfr. Barry \& Ohland, 2009, p. 388). What is problematic is, precisely, the morality of a situation whose factual or technical elements are already known. ${ }^{7}$ When we question the morality of a high-risk medical operation, we do not ask about the theoretical status of the operation itself, but rather we seek the principles that indicate the best course of action. Clearly, some situations raise significant ontological or anthropological questionsjust think of the classic problem of abortion, where the ontological status of the fetus is under debate-. However, these questions go beyond the field of applied ethics and are the research objects of other disciplines like meta-ethics, or ontology, for example. This kind of question tends to be of secondary importance within applied ethics, while prevalence is attributed to a methodology for making decisions in concrete situations (cfr. Bosk, 1999, pp. 47-68). This is the beacon of applied ethics: not to address theoretical speculations about the elements that make up its application, but rather to put itself into practice. We could say that "applied ethics is that intellectual locale where theory meets praxis" (Ezra, 2006, p. IX).

Among the recently introduced subdisciplines in applied ethics is environmental ethics (Valera, 2016b, pp. 289-292). According to the ideas mentioned above, environmental ethics is specialized in resolving the ethical dilemmas of environmental issues, such as pollution, resource scarcity, biodiversity loss and others (cfr. Traer, 2013, pp. 1354). However, although it may seem that the task of environmental ethics should be the same as that of any applied ethics, the paradigms of environmental ethics raise very general and far-reaching questions, without becoming entrapped in questions about the application.

As noted before, the task of applied ethics does not consist of theoretical speculation about its object, and even less in raising ontological or metaphysical questions about reality. However, this is what usually happens in environmental ethics, not because of any effort to arbitrarily betray the practical nature of its thought, but because its object of study arouses such considerations. In fact, the most critical

7 We can find an excellent example in the area of bioethics (cfr. Hedgecoe, 2004, pp. 122-123). 
question of environmental ethics is usually about the ontological status of nature and the relationship of human beings to it (cfr. Bordeau, 2004, p. 10). Since environmental problems imply a responsibility towards the entire biosphere, which we intuitively identify with nature itself, they take up many of the issues of the philosophy of nature of yesteryear, a type of reflection that seems unusual in a post-metaphysical age (cfr. Habermas, 2001).

The reason that environmental problems raise this kind of question is that the object of environmental ethics is broader than those of other applied ethics. The spectra of issues addressed by legal, medical, engineering, journalist ethics can be determined with certain precision, while the spectrum of objects of the environmental area can be allembracing. The mere distinction between natural regions and civilization, which is of paramount importance for many environmental problems, also raises the question of the place of humans in the natural world. It is inevitable that we wonder what the environment is and whether or not this term includes everything around us, including human beings and our cultures. ${ }^{8}$ Therefore, it is evident that since its inception, environmental ethics has been challenged to complex questions of an ontological character that push concrete decision-making into the background. This is evident in Arne Næss's Ecosophy T (Arne Næss, 1989a, p. 14), or in Jonas's Imperative of Responsibility, which stems from the necessity of a metaphysical question (cfr. Jonas, 1985, p. X).

Finally, it is clear the question that environmental problems pose goes far beyond that of providing a fix to concrete dilemmas that may appear in the field. Rather, they bring to our attention the fundamental issue of how human action relates to the totality of nature, and so they strike change into a much larger portion of our worldviews than we could prevent. The cosmological character of this inquiry leads to asking if environmental ethics is really (only) a form of applied ethics.

\section{The Origin, the Crisis and the Questions}

The beginnings of environmental ethics are necessarily associated with recent technological developments (cfr. Valera, 2016b, pp. 291-292; Valera, 2017, pp. 396-398). The origin of environmental ethics coincides,

8 A good answer to this problem may be found in Jakob von Uexküll (1909), Umwelt und Innenwelt der Tiere. 
de facto, with a change in action (cfr. Jonas, 1985, p. 7) defined by the unpredictable possibilities that new technologies have brought with them. Humans now have the ability to transform the world in ways they have never had before in history (cfr. Attfield, 2018, p. 4), given that "before our time man's inroads into nature [...] were essentially superficial and powerless to upset its appointed balance" (Jonas, 1985, p. 3). From there, reflections began to emerge on issues like resource depletion (cfr. Jonas, 1985, p. 163), the danger posed by pesticides (cfr. Carson, 1962), climate change and the destruction of the planet itself (cfr. Potter, 1988, pp. 31-35), and different apocalyptic scenarios, just to mention some problems related to the so-called "environmental/ ecological issue."

Thus emerges the idea of an "ecological crisis," that is, a crisis that reflects the impossibility of dwelling (on) this planet. The crisis does not refer to already existing living conditions, but to the impossibility of dwelling itself: human beings see themselves as eradicated in their relations with the world, to the point they perceive their space, in others words, their existence in this world, as "impossible." In this sense, Heidegger's words clarify and give sense to this crisis:

The real plight of dwelling is indeed older than the world wars with their destruction, older also than the increase of the earth's population and the condition of the industrial workers. The real dwelling plight lies in this, that mortals ever search anew for the nature of dwelling, that they must ever learn to dwell. [...] What if man's homelessness consisted in this, that man still does not even think of the reed plight of dwelling as the plight (1971a, p. 159)?

The ecological crisis is so more internal than external to the human being, given the fact that it is related to the possibilities of expressing its humanity, i.e., of living as a human being on this planet. The following statement affirms this: "The human world is not a separate entity or a selfdependent reality. Man lives in physical surroundings which constantly influence him and set their seal upon all the forms of his life" (Cassirer, 1953, p. 255). Consequently, we can correctly speak of an ecological crisis (without any contradiction), because the crisis is fundamentally existential as the "external" world constitutes an important part of our 
human existence. ${ }^{9}$ Humans do not exist in isolation from their context, something the phenomenological speculation has strongly emphasized; indeed, the relationship between human beings and nature is "full of meaning" at both the symbolic and experiential levels. It is, therefore, possible to contemplate the ecological crisis, keeping in mind that humans are essentially ecological beings (Næss, 1989b), that is, situated beings. ${ }^{10}$

If the ecological crisis is definable as an existential dynamism in the context of possibilities offered by new technologies (cfr. Valera, 2016b, p. 291), including the dangers that they bring, the first objective of environmental ethics should be to interpret and give an answer to this crisis. Hence emerges the essential question we want to answer through this article: Is environmental ethics only a "practical response" to this crisis, or can we characterize it as "something more"? In other words, can we correctly affirm that "Environmental ethics may be understood to be but one among several new sorts of applied philosophies, the others of which also arose during the seventies, that is, it may be understood to be an application of well-established conventional philosophical categories to emergent practical environmental problems" (Callicott, 1984, p. 299)? If this is not the case, we have to justify the need for applied ethics beyond the requirement of quick responses to current ecological problems. We can also affirm that environmental changes generated by technological developments are contingencies that have raised the "environmental issue" again, evoking questions that were already present in human nature and history. In a few words, we affirm that environmental ethics goes beyond the simple solution of emerging problems. So, what we point to is not so much the application of a given paradigm, but the challenge of rethinking our way of inhabiting the world (cfr. Valera, 2013, pp. 42-44), which is a more complex task with more indefinite boundaries, and undoubtedly more stimulating.

9 For more detail on the concept of experience as used in this context, please see John Dewey (1958) and Russo \& Valera (2015).

10 We take up again this expression from the Spanish philosopher Leonardo Polo (1996, pp. 50-51), which uses the adjective "situated" to define human freedom. 


\section{The Necessary Articulation Between Cosmology and Dwelling: The Oikos}

Concerning this challenge, it is essential to identify the sources of difficulties in understanding our contemporary relation with nature. After the influence of the ideals of the modern age, technology and instrumental rationality have misrepresented and misunderstood the relationship between humans and their environment. This type of instrumental rationality has thus converted nature and its resources into simple means that should be exploited to meet human needs. This conception of nature is rooted in "extreme anthropocentrism", in which homo economicus is considered the owner and lord of all that surrounds him:

Homo economicus is a one-dimensional creature, rational indeed, but with no conception of the ends of life, no idea that desires can be judged and found wanting, no ability to renounce what he wants for the sake of what he values (Scruton, 2012, pp. 243-244).

Keeping the above in mind, exacerbated industrialism and accelerated technological advances have radically fractured the relationship between humans and their surroundings (cfr. Stine \& Tarr, 1998, pp. 601-640; Light, 2001, pp. 7-35; Anderberg, 1998, pp. 311-320). Based on this hiatus, we find "the cult of human competence, the pursuit of 'mastery over nature' and the belief that all our problems can be solved by more technology" (Scruton, 2012, pp. 243-244). Consequently, a serious study of environmental problems should consider this context, or at least consider Arne Næss's (1989a, p. 87) fundamental question: "How are the ecologically destructive, but 'firmly established ways of production and consumption' to be changed?"

Environmental speculation has often demonized all technologies, viewing them as antithetical to a real "ecological conversion" (Brand \& Fisher, 2013, pp. 235-254), without really understanding the role of technology in this conversion. Technologies form a significant part of our dwelling (cfr. Valera, 2013, pp. 193-199). Through a famous sentence, Næss explained how the problem is not with technology, but rather with how we relate to technology: 
A central slogan of ecosophical lifestyle: "Simple in
means, rich in ends". It is not to be confounded with
appeals to be Spartan, austere and self-denying. The
ecosophical lifestyle appreciates opulence, richness,
luxury, affluence. However, the joys are defined in terms
of quality of life, not standard of living (Næss, 1989a, p. 88).

In this sense, our way of dwelling in the world requires rethinking our use of technology, and not assuming superficial technophobic or technophilic attitudes.

Both attitudes (technophobia and technophilia) lead to oikophobia, that is, to hostility to the home and dwelling, based on the mistaken understanding of our role in the world (and of the means we use) (cfr. Scruton, 2012, p. 246). In this sense, oikophobia is much more dangerous than moral and political indifference to environmental problems, given that it disconnects us not only from home, but also from the world we live in.

On the contrary, we seem to need an oikophilia, that is, a "love of home," habitat and nature:

Human beings, in their settled condition, are animated by an attitude of oikophilia: the love of the Oikos, which means not only the home but the people contained in it, and the surrounding settlements that endow that home with lasting contours and an enduring smile. The Oikos is the place that is not just mine and yours, but ours. It is the stage-set for the first-person plural of politics, the locus, both real and imagined, where it all takes place (Scruton, 2012, p. 227).

How can we appreciate that Oikos is "our" place, that we all inhabit a "common" world? This "sense of belonging to the world" is the root of oikophilia, which is central in our relationship with everything that surrounds us, that is, "dwelling." In the words of Mircea Eliade (1976, p. 27), who highlights the depth of the concept of house beyond the simple "home": "The house [oikos] is not an object, a 'machine to live in'; it is the universe that man constructs for himself by imitating the paradigmatic creation of the gods, the cosmogony."

If our dwelling is the central dimension that defines our relationships with our surroundings, or in other words, is the expression of our way 
of being (or of living) on Earth, it is unseemly not to refer to the famous conference by Martin Heidegger in 1951, Building, Dwelling, Thinking. Here it is shown with absolute clarity that "dwelling" conditions are not merely material, but also ontological, and that "dwelling" should not be configured as only one of many human activities. Quite the opposite, "the concept of dwelling indicates an attempt to think of 'the event of space'"' (Harrison, 2007, p. 627).

In this sense, Heidegger's reflections on poetic dwelling are valuable, which is not about "beautifying" what we build through art

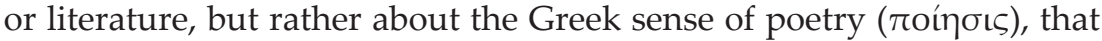
refers to every act of creation or human action that gives sense to what is (cfr. Heidegger, 1971b, p. 214). This means that humans poetically dwell on the earth, because their mode of existence implies the ongoing creation of themselves, of meaning for their existence. At this point, it is necessary to make a distinction among dwelling and building: while dwelling expresses the way human beings are on the earth, building represents the modulations of the different ways that we live on the earth (cfr. Heidegger, 1971a, p. 147). It is important to clarify that the relationship between dwelling and building is not based on a means-ends relationship. Buildings are not means to be acquired, like the ultimate aim of dwelling (cfr. Heidegger, 1971a, p. 144). According to Heidegger, dwelling is an essential characteristic of human beings; humans build their dwellings and unfold their being through them. In other words, human beings build their homes because their previous existential condition is dwelling, and consequently, building is a "modulation" or "expression" of it. Building implies creating an opening to make human dwelling visible, and it is not the result of production, its essence instead lies in making human dwellings possible. It can be expressed on the one hand by housing, carving, buildings and other material implications of dwelling, and on the other hand, trough the cultivation and care of nature and all the fruits that it brings us. Consequently, inhabiting implies stewardship given that taking care does not merely consist of not doing anything wrong. Genuine caring is something positive and happens beforehand when we leave something in its essence (cfr. Heidegger, 1971a, p. 147).

Thanks to this renewed conception, we discover something of vital importance in that dwelling is both doing (activity) and a way of being; it establishes, so, a bridge between the ontological dimension and practice (cfr. Young, 2000, pp. 190-194). In this way, reflections about dwelling 
are both ontological and at the same time ethical, given that it does not circumscribe to local limitations and immediate actions, but rather is an activity that impels a world (Welt) unto unveiling itself. Thus, Oikos appears and reveals itself as what we called Nature, which we decide to build and take care of (Todres \& Galvin, 2010).

This is the meeting point with the Oikos of ecology (Oikos-logos), understood in its full depth. What we call environment (Umwelt) no longer appears merely as a set of biotic and abiotic conditions, but also with its cosmological background, in which external and internal elements penetrate each other simultaneously (cfr. Harrison, 2007, p. 628). Oikos is precisely nature, which in our concrete instance we identify as a world composed of ecosystems and living beings: the planet Earth. ${ }^{11}$ Focusing on Oikos, environmental ethics investigates what this place we inhabit is and what belongs to it. Consequently, this reflection proceeds to distinguish what belongs to nature and what does not, recognizing its limits, constituents, and properties.

As soon as that world, which in principle was only an abstraction, becomes an ontological dimension comprised of its concrete entities, it becomes cosmological, and through the "bridge" of inhabiting that dimension, is connected to the practical (Potter, 1971). The ecological crisis has shown us the consequences of turning a deaf ear to a profound conception of dwelling, to rediscover it reveals that the inhabited, the environment, is nature in its cosmological background. It is clear, thus, that the concern of environmental ethics cannot be limited merely to applied ethics, because it is not only about applying principles to concrete situations, but rather about elucidating the gap between nature and ethics. So, considerations of this discipline have to build the bridge from the practical to the cosmological, from the extensionally smaller, to the extensionally more encompassing.

11 In a more personal sense, it would not be correct to speak of the "environment" of the human being, since, as Arnold Gehlen (1988, p. 71) points out, "the cultural world exists for man in the same way in which the environment exists for an animal. For this reason alone, it is wrong to speak of an environment, in a strictly biological sense, for man. His world-openness is directly related to his unspecialized nature [...]. The clearly defined, biologically precise concept of environment is thus not applicable to man, for what 'environment' is for animals, "the second nature' or culture, is for man." 


\section{Are We Talking About the Paradigms of Environmental Ethics?}

To demonstrate that effectively the classical paradigms of environmental ethics are not merely paradigms of applied ethics (as this term is generally understood), we will briefly review the main ones and highlight the elements that are outside the realm of Applied Ethics.

\section{a. Deep Ecology}

Firstly, it is impossible not to mention Deep Ecology, whose intellectual leader is the Norwegian philosopher Arne Næss (cfr. Valera, 2015; Glasser and Drengson, 2005). In the famous manifesto of the movement, Næss proclaimed the centrality of the principle of the independence of nature's values from its utility to humans (Arne Næss, 1973, pp. 95-100): ${ }^{12}$ "The well-being and flourishing of human and nonhuman life on earth have intrinsic value, inherent worth. This value is independent of the usefulness of the nonhuman world for narrow human purposes" (Næss, 2005, p. 18). Deep Ecology emerged around the idea that nature has its own moral status and value independent of human judgment, maintaining a maximum level of perfection, a concept inherited from Spinoza, according to Næss (1993). This paradigm, which today is no longer the most widely used, is probably the most complete and systematic. Based on a well-defined research methodology ("depth" as a method to perceive spontaneous experience-cfr. Næss, 1995, p. 210), it describes a coherent cosmology and ontology (Gestalt Ontology) (Næss, 1989b, pp. 134-137), and finally, some ethical guidelines directed at respecting the intrinsic value of every form of life, that is, the selfrealization of every one of these forms (Næss, 1987, pp. 35-42).

\section{b. Ecofeminism}

Beginning with the critique (already elaborated by Deep Ecology) of the mechanistic reduction of nature inherited by the scientific revolution

12 About the intrinsic value of nature, which is fundamental in the debate on environmental ethics, please see: Callicott (1985, pp. 257-275), Rolston (1988) and Sandler (2012). 
(d'Eaubonne, 1974), ${ }^{13}$ ecofeminism considers the "mercification" brought by human beings, and more specifically humans of the male gender. Thus, women and nature share a condition of subjugation by men. This thesis, together with the famous critique of androcentrism (a subclass of anthropocentrism) (cfr. Marcos, 2001, p. 148), is the base of the social movement of ecofeminism, ${ }^{14}$ in which the most recognized thinkers are Val Plumwood (1995, pp. 155-164), Karen J. Warren (1987, pp. 3-20), Ariel Salleh (1984, pp. 335-341), Maria Mies and Vandana Shiva (1993).

\section{c. Environmental Virtue Ethics}

Among the most popular tendencies in current environment ethics, without any doubt, is environmental virtue ethics, which combines the idea of human flourishing with respect for nature: "It is the human excellence whose domain is environmental interactions and relationships" (Sandler, 2004, p. 481). Contrary to general expectation, this ethical theory also supports the existence of an intrinsic value of nature. However, the recovery of virtues in the environmental debate strips away the density and depth of Aristotelian concepts. A given human nature no longer exists, but rather just a set of human properties, as Cafaro and Sandler (2005) point out, to make space for the development of some of the characteristics that could improve the "cure" and "respect" for nature's intrinsic value (Sandler, 2007). In this sense, it is an environmental ethic tout court. Consequently, it does not engage with metaphysical or cosmological issues but preserves a "prescriptive" or "normative" character (Sandler, 2004, p. 491).

\section{d. Environmental Pragmatism}

As environmental ethics was hugely influential in the United States, it is impossible not to mention environmental pragmatism, which remains as one of the most widespread trends in this area, despite the considerable theoretical difficulties that arise as it merges into an

13 In fact, ecofeminism "represents the union of the radical ecology movement, or what has been called 'deep ecology', and feminism" (Ruether, 1996, pp. 35-50).

${ }_{14}$ This is a social phenomenon rather than a proper ethical theory. At the theoretical level, ecofeminism seems to use mostly clichés and is characterized mainly as a social movement. Eco-anarchism is among the social phenomena related to ecology, as represented by Murray Bookchin (1971). 
essentially anti-anthropocentric tradition. ${ }^{15}$ The advantage of pragmatic environmental ethics is immediately visible in a context where there are more urgent problems to be solved than solutions to be found. In this sense, pragmatism offers an "ecology of values" (Weston, 1985, p. 322), totally dependent on the conditions to be dealt with, without needing to appeal to "thick concepts" about the nature of the value or the value of nature itself. In fact, Weston argues:

The problem is not to devise still more imaginative or exotic justifications for environmental values. We do not need to ground these values, pragmatists would say, but rather to situate them in their supporting contexts and to adjudicate their conflicts with others- a subtle enough difference at first glance, perhaps, but in fact a radical shift in philosophical perspective (1985, p. 322)

\section{e. Ethics of Responsibility}

It is probably the most challenging paradigm to define concerning authors, issues, scope, and limits, since it maintains a crosscutting and common perspective with different visions. If we use the classic categories, the ethics of responsibility is characterized as the most "anthropocentric" of the different paradigms of environmental ethics, focusing more on the responsibility (or cure) that human beings must develop for non-human entities, in place of the proclamation of the existence of their intrinsic value. In addition to Jonas, mentioned above, the most important thinker in this area is the Australian John Passmore (1974), author of the classic Man's Responsibility for Nature ${ }^{16}$ and creator

15 Most pragmatic proposals of environmental ethics, in fact, clash with the difficulty of justifying the existence of an intrinsic value of nature in the theoretical framework of pure pragmatism: "Pragmatism, it is alleged, would undermine the very possibility of an environmental ethic by arguing against its central and ultimate foundation, intrinsic value" (McDonald, 2004, p. xiv). On anti-anthropocentrism, see Norton (1995, pp. 341-358).

16 It is worth noticing that this text is considered to be the first and most complete philosophical reference on the issue, although it is controversial because it revives Western ethics and metaphysics, representing a minority view among reflections on environmental ethics (cfr. Katz, 1991, pp. 79-86). 
of the idea of Earth Stewardship, ${ }^{17}$ which is aimed at perfecting nature itself (cfr. Sessions, 1987, pp. 105-125).

\section{f. Deontological Environmental Ethics}

Kantian philosophy is generally considered inadequate to underlie direct responsibilities for non-human beings, since the "ethical" is considered the exclusive domain of beings with free or rational will (in effect, human beings) (cfr. Svoboda, 2012, pp. 143-144). In this sense, the responsibilities to non-human beings are nothing more than indirect (cfr. Svoboda, 2012, pp. 143). Despite this apparent incompatibility, there is a directly Kantian deontological environmental tradition (cfr. Gillroy, 1998, pp. 131-155; Gillroy, 2001; Wood \& O'Neill, 1998, pp. 189-228) that links respect for non-human beings with reaching human perfection (cfr. Svoboda, 2012, p. 157), and others that, while they do not identify as Kantian, used Kantian deontological concepts to consider responsibilities for non-human beings and the rights of these beings. ${ }^{18}$ Both currents deal with the same questions about the moral value of non-human beings and the environment, and whether non-human beings have an intrinsic value similar to that of human beings.

\section{g. Ecophenomenology}

This paradigm applies epistemological principles and phenomenological methodologies to environmental thought. The primary objective of this approach is to face nature putting aside naturalist metaphysics.

On the one hand, Husserlian-inspired eco-phenomenology plays into the possibility of constituting the environment ${ }^{19}$ through an experience that legitimately accounts for its phenomenological appearance (Embree, 2012). As well as giving an account of axiological elements in nature itself (good, intrinsic value, beauty, etc.), it distances itself from a focus on solely the causal links of the phenomena, that is, a search for "the moral sense of nature" (Kohák, 1987, p. 13).

17 In this context, we can also mention Paul Taylor's classic (1986), Respect for Nature: A Theory of Environmental Ethics.

18 For example, see Tom Regan's works (1975, pp. 181-214; 2004, pp. 1124), where Kantian philosophy is used to ground animal rights.

19 In the sense of Husserl's constitutive phenomenology. 
On the other, the eco-phenomenology of Heideggerian inspiration does not seek value in nature, but instead considers that this possibility remains the exclusive possession of the Dasein. In this sense, it seeks an ontological more than an axiological solution to anthropocentrism. The argument is basically that, "for something 'to be' means for it to manifest itself, in the sense of being interpreted, understood, or appropriated by human Dasein" (Zimmerman, 2012, p. 74). However, as soon as that same activity allows the Dasein to constitute itself as such. It is termed to "'let beings be', by allowing them to manifest themselves in their various kinds of intelligibility" (Zimmerman, 2012, p. 74). In this sense, of its powers it does not follow that it can do what it wants with other beings, but rather, "endowed with great disclosive capacities, Dasein is also burdened with unparalleled responsibilities to 'care' for beings" (Zimmerman, 2012, p. 91).

\section{Towards an Environmental Philosophy: A Proposal}

An initial observation of the different "classical" paradigms of environmental ethics yields at least one initial conclusion: that not all of these can be considered "applied" paradigms. The reasons for this statement vary according to the different paradigms (for example, the concept of applied ethics is related to "analytical" and not "continental" reflection). Finally, it makes sense to affirm that the so-called paradigms of environmental ethics are not just that. Specifically, the paradigms that are the least adapted to this latest consideration are deep ecology, ecofeminism and ecophenomenology, given that they highlight elements of environmental reflection that cannot be adequately defined as "ethical," but rather ontological (deep ecology), political (ecofeminism) or methodological (ecophenomenology). Similarly, the ethics of responsibility also resists the connotation of applied ethics, since it emphasizes the conditions that make an environmental ethics possible, rather than the application of principles to specific environmental cases. In these regards, we have two options:

1. To restrict the scope of environmental ethics and note that only some of the paradigms (environmental virtue ethics, environmental pragmatism and deontological environmental ethics) are properly paradigms of environmental ethics, excluding models that for different reasons do not fit such a reductive definition. 
2. To reconsider environmental ethics as an area of reflection that would be better renamed as "environmental philosophy" to include aspects that simple environmental ethics (like applied ethics) cannot explain, because some questions are beyond its scope of action.

In the context of these alternatives, it is essential, firstly, to emphasize that we cannot be satisfied with arbitrary solutions, but it is also essential to ask the question again, "What is the formal object of so-called environmental ethics?" Russo answered this question in the following way:

Philosophical environmentalism [...] does not question the scope of resources and their exploitation, the load capacity of the biosphere or calculating thresholds or the value of natural capital and accounting methods, but rather poses ecological questions in general and fundamental terms of dwelling the Earth with other living things (Russo, 2000, pp. 201-202).

If the primary ethical object of a serious environmental consideration is the way we live in the world, we need an environmental philosophy, which rightly raises the issue of dwelling from the different conditions that this expresses (ontological, methodological, normative, and axiological conditions, among others). From there, it is possible to detach the work of applying the reflections on the specific case, with the extreme creativity that this hermeneutic operation implies, until reaching the most concrete particulars.

This implies that environmental ethics, under the multiplicity of its paradigms and as it has been presented to date, is not only not simply, but should not exclusively be an applied ethics.

\section{Bibliography}

Anderberg, S. (1998). Industrial Metabolism and the Linkages Between Economics, Ethics and the Environment. Ecological Economics, 24(23), 311-320.

Attfield, R. (2018). Environmental Ethics: A Very Short Introduction. Oxford University Press.

Barry, B. E. \& Ohland, M. W. (2009). Applied Ethics in the Engineering, Health, Business, and Law Professions: A Comparison. Journal of Engineering Education, 98(4) 377-388. 
Beauchamp, T. (2007). History and Theory in Applied Ethics. Kennedy Institute of Ethics Journal, 17(1), 55-64.

Bookchin, M. (1971). Post-Scarcity Anarchism. Wildwood.

Bordeau, P. (2004). The Man Nature Relationship and Environmental Ethics. Journal of Environmental Radioactivity, 72, 9-15.

Bosk, C. (1999). Professional Ethicist Available: Logical, Secular, Friendly. Daedalus, 128(4), 47-68.

Brand, R. \& Fisher, I. (2013). Overcoming the Technophilia/Technophobia Split in Environmental Discourse. Environmental Politics, 22(2), 235254.

Cafaro, P. \& Sandler, R. (2005). Environmental Virtue Ethics. Rowman \& Littlefield.

Callicott, J. B. (1984). Non-Anthropocentric Value Theory and Environmental Ethics. American Philosophical Quarterly, 21(4), 299309.

(1985). Intrinsic Value, Quantum Theory, and Environmental Ethics. Environmental Ethics, 7(3), 257-275.

Carson, R. (1962). Silent Spring. Houghton Mifflin.

Cassirer, E. (1953). An Essay on Man. An Introduction to a Philosophy of Human Culture. Doubleday.

Cortina, A. (1996). El Estatuto de la Ética Aplicada. Hermenéutica Crítica de Las Actividades Humanas. Isegoría. Revista de filosofía moral y política, 13, 119-127. (2007). Ética aplicada y democracia radical. Tecnos.

d'Eaubonne, F. (1974). Le féminisme ou la mort. P. Horay.

Dewey, J. (1958). Experience and Nature. Dover Publications.

Eliade, M. (1976). Occultism, Witchcraft, and Cultural Fashions: Essays in Comparative Religion. University of Chicago Press.

Embree, L. (2012). The Possibility of Constitutive Phenomenology of the Environment. In T. Toadvine \& C. S. Brown (eds.), EcoPhenomenology: Back to the Earth Itself. (pp. 37-50). State University of New York Press.

Ezra, O. (2006). Moral Dilemmas in Real Life. Current Issues in Applied Ethics. Springer.

Gadamer, H.-G. (2013). Truth and Method. Bloomsbury.

Gehlen, A. (1988). Man: His Nature and Place in the World. Columbia University Press. 
Gillroy, J. M. (1998). Kantian Ethics and Environmental Policy Argument: Autonomy, Ecosystem Integrity, and Our Duties to Nature. Ethics and the Environment, 3(2), 131-155.

(2001). Justice and Nature: Kantian Philosophy, Environmental Policy and the Law. Georgetown University Press.

Glasser, H. \& Drengson A. (2005). The Selected Works of Arne Næss, Springer.

Habermas, J. (2001). Die Zukunft der menschlichen Natur. Auf dem Weg zu einer liberalen Eugenik? Suhrkamp.

Harrison, P. (2007). The Space between Us: Opening Remarks on the Concept of Dwelling. Environment and Planning D: Society and Space, 25(4), 625-647.

Hedgecoe, A. (2004). Critical Bioethics: Beyond the Social Science Critique of Applied Ethics. Bioethics, 18(2), 120-143.

Heidegger, M. (1971a). Building, Dwelling, Thinking. In M. Heidegger, Poetry, Language, Thought. (pp. 143-161). Harper \& Row.

(1971b). ...Poetically Man Dwells... In M. Heidegger, Poetry, Language, Thought. (pp. 213-229). Harper \& Row.

Jonas, H. (1985). The Imperative of Responsibility: In Search of an Ethics for the Technological Age. University of Chicago Press.

Katz, E. (1991). Ethics and Philosophy of the Environment: A Brief Review of the Major Literature. Environmental History Review, 15(2), 79-86.

Kohák, E. (1987). The Embers and the Stars. University of Chicago Press.

LaFollette, H. (2005). The Oxford Handbook of Practical Ethics. Oxford University Press.

Leopold, A. (1949). A Sand Country Almanac and Sketches Here and There. Oxford University Press.

Light, A. (2001). The Urban Blind Spot in Environmental Ethics. Environmental Politics, 10(1), 7-35.

Marcos, A. (2001). Ética ambiental. Universidad de Valladolid.

McDonald, H. P. (2004). John Dewey and Environmental Philosophy. State University of New York Press.

Morscher, E., Neumaier, O. \& Simons, P. (2012). Applied Ethics in a Troubled World. Springer.

Minteer, B. A. \& Collins J. P. (2008). From Environmental to Ecological Ethics: Toward a Practical Ethics for Ecologists and Conservationists. Science and Engineering Ethics, 14(4), 483-501.

Mies, M. \& Shiva, V. (1993). Ecofeminism. Zed Books. 
Næss, A. (1973). The Shallow and the Deep, Long-Range Ecology Movement. A Summary. Inquiry, 16(1-4), 95-100.

(1989a). Ecology, Community and Lifestyle: Outline of an Ecosophy. Cambridge University Press.

(1989b). Ecosophy and Gestalt Ontology. The Trumpeter, 6(4), 134137.

(1987). Self-Realization: An Ecological Approach to Being in the World. The Trumpeter, 4(3), 35-42.

(1993). Spinoza and the Deep Ecology Movement. Eburon.

(1995). Deepness of Questions and the Deep Ecology Movement. In G. Sessions (ed.), Deep Ecology for the 21st Century. (pp. 204-212). Shambhala.

(2005). The Basics of Deep Ecology. In H. Glasser, A. Drengson (eds.), The Selected Works of Arne Næss. Vol. X. (pp. 13-20). Springer.

Norton, B. (1995). Why I Am Not Anthropocentrist. Environmental Ethics, $17,341-358$.

Passmore, J. (1974). Man's Responsibility for Nature: Ecological Problems and Western Traditions. Charles Scribner's Sons.

Plumwood, V. (1995). Nature, Self, and Gender. Feminism, Environmental Philosophy, and the Critique of Rationalism. In R. Elliot (ed.), Environmental Ethics. (pp. 155-164). Oxford University Press.

Polo, L. (1996). La persona humana y su crecimiento. EUNSA.

Potter, V. R. (1971). Bioethics. Bridge to the future. Prentice Hall. (1988). Global Bioethics. Building on the Leopold Legacy. Michigan State University Press.

Regan, T. (1975). The Moral Basis of Vegetarianism. Canadian Journal of Philosophy, 5(2), 181-214.

(2004). The Day May Come: Legal Rights for Animals. Animal Law, $10,11-24$.

Rolston, H. (1988). Environmental Ethics: Duties to and Values in the Natural World. Temple University Press.

Russo, M. T. \& Valera, L. (2015). Invito al ben-essere. Lineamenti di etica. Aracne.

Russo, N. (2000). Filosofia ed ecologia. Idee sulla scienza e sulle prassi ecologiche. Guida.

Ruether, R. (1996). Ecofeminism: Symbolic and Social Connections of the Oppression of Women and the Domination of Nature. Feminist Theology, 3(9), 35-50. 
Salleh, A. (1984). Deeper than Deep Ecology: The Eco-Feminist Connection. Environmental Ethics, 6(4), 335-341.

Sandler, R. (2004). Towards an Adequate Environmental Virtue Ethic. Environmental Values, 13(4), 477-495.

(2007). Character and Environment: A Virtue-Oriented Approach to Environmental Ethics. Columbia University Press.

(2012). Intrinsic Value, Ecology, and Conservation. Nature Education Knowledge, 3(10), 4.

Scruton, R. (2012). How to Think Seriously About the Planet. The Case for an Environmental Conservatism. Oxford University Press.

Sessions, G. (1987). The Deep Ecology Movement: A Review. Environmental Review, 11(2), 105-125.

Singer, P. (1986). Applied Ethics. Oxford University Press.

Stine, J. K. \& Tarr, J. A. (1998). At the Intersection of Histories: Technology and the Environment. Technology and Culture, 39(4), 601-640.

Svoboda, T. (2012). Duties Regarding Nature: A Kantian Approach to Environmental Ethics. Kant Yearbook, 4(1), 143-144.

Taylor, P. (1986). Respect for Nature: A Theory of Environmental Ethics. Princeton University Press.

Todres, L. \& Galvin, K. (2010). Dwelling-Mobility: An Existential Theory of Well-Being. International Journal of Qualitative Studies on Health and Well-being, 5(3). DOI: https://doi.org/10.3402/qhw.v5i3.5444.

Traer, R. (2013). Doing Environmental Ethics. Westview Press.

Valera, L. (2013). Ecologia umana. Le sfide etiche del rapporto uomo/ambiente. Aracne.

_ (2015). Arne Næss. Introduzione all'ecologia. ETS.

(2016a). El futuro de la ecología: la sabiduría como centro especulativo de la ética ambiental. Cuadernos de bioética, 27(3), 329338.

(2016b). ¿Qué es la ética ambiental? Desde sus raíces hacia el futuro. Cuadernos de bioética, 27(3), 289-292.

(2017). La bioética de Potter: la búsqueda de la sabiduría en el origen de la bioética y de la ética ambiental. Medicina y ética. Revista internacional de bioética, deontología y ética médica, 28(2), 396-398.

Von Uexküll, J. (1909). Umwelt und Innenwelt der Tiere. Springer.

Warren, K. J. (1987). Feminism and Ecology: Making Connections. Environmental Ethics, 9(1), 3-20.

Weston, A. (1985). Beyond Intrinsic Value: Pragmatism in Environmental Ethics. Environmental Ethics, 7, 321-339. 
Wood, A. \& O'Neill, O. (1998). Kant on Duties Regarding Nonrational Nature. Proceedings of the Aristotelian Society, 72, 189-228.

Young, J. (2000). What is Dwelling? The Homelessness of Modernity and the Worlding of the World. In M. A. Wrathall \& J. Malpas (eds.), Essays in Honor of Hubert L. Dreyfus: Heidegger, Authenticity, and Modernity. (pp. 187-204). The MIT Press.

Zimmerman, M. (2012). Heidegger's Phenomenology and Contemporary Environmentalism. In T. Toadvine \& C. S. Brown (eds.), EcoPhenomenology: Back to the Earth Itself. (pp. 73-102). State University of New York Press. 
